\title{
ENERGY DISSIPATION BEHAVIOURS AND SEISMIC REDUCTION PERFORMANCE OF A PROPOSED VELOCITY AND DISPLACEMENT DEPENDENT HYDRAULIC DAMPER (VDHD)
}

\author{
Wen-Pei Sung ${ }^{1}$, Ming-Hsiang Shih $^{2}$, Yu-Kuang Zhao ${ }^{3}$ \\ ${ }^{1}$ Department of Landscape Architecture, National Chin-Yi University, Taichung, Taiwan 41111 \\ ${ }^{2}$ Department of Civil Engineering, National Chi-Nan University, Nan-Tou, Taiwan 545 \\ E-mail: iloveaachen@gmail.com (corresponding author) \\ ${ }^{3}$ Institute of Refrigeration, Air Conditioning and Energy Technology \\ National Chin-Yi University, Taichung, Taiwan 41111
}

Received 29 Mar. 2009; accepted 14 May 2010

\begin{abstract}
A new oil-pressure Velocity and Displacement Dependent Hydraulic Damper (VDHD) is proposed by adding an additional Relief Valve parallel to the Throttle Valve with a different aperture size. This objective is to obtain an adaptive control by changing the damping coefficient of the VDHD for better control of structural movement during earthquake. In order to simulate its actual energy elimination, a mathematical analysis model is developed based on the Maxwell Model, which is modified by adding a serial friction model and a small damper parallel to the friction model in this study. The mathematical simulated results are compared with the actual energy-dissipating behaviours of this proposed damper. The comparison shows that this proposed mathematical modelling could accurately simulate the relation of force and displacement as well as the relation of force and velocity during the process of energy dissipation. In addition, results of both the laboratory shaking table test and simulation analyses are used to test and verify the seismic reduction performance of this proposed damper. The experimental and simulation results show that in spite of the magnitude of the earthquake, the proposed VDHD device has a superior effect on the control of structural displacement by achieving effective acceleration reduction.
\end{abstract}

Keywords: VDHD; modified maxwell theory; discrete solution; passive energy-dissipating device, shaking table test, simulated structural reduction responses.

\section{Introduction}

The structural control system using a hydraulic damper using oil viscosity to dissipate the dynamic energy can be divided into three categories including: the active control system, semi-active control system and passive control system (Soong and Spencer 2002; Soong and Cimellaro 2008; Rodellar 2004; Plummer 2006). These hydraulic dampers can simultaneously reduce the structural displacement and acceleration reaction to provide effective result depending on the requirement of the structure; they have less problem of life cycle as well. Many devices, such as the Taylor device (Lee and Taylor 2001), Electrorheological damper (Xu et al. 2000; Su et al. 2003; Kim et al. 2002; Shulman et al. 2006; Wereley 2008; Song et al. 2002) and Magnetroheologrical damper (Dyke et al. 1998; Pranoto et al. 2004; Wang and Meng 2005; Xu and $\mathrm{Li}$ 2008; Loh et al. 2007), semi-active hydraulic damper developed by Kobori (Kurata et al. 1999; 2000; Kobori et al. 1999) and Shih and Sung (Shih et al. 2002, 2003; Shih and Sung 2004; 2006) are currently available. These dampers basically function by shifting the size of the orifice to promptly adjust the shear stress of oil or by using specific valves to produce the proper hydraulic effect (Shih et al. 2002, 2003; Shih and Sung 2004, 2006).
In this research, a new device, Velocity and Displacement Dependent Hydraulic Damper, VDHD is proposed to control the energy-dissipating element of the passive control system. The main design concept is based on the energy-dissipating component that the damping force can be generated by varying the flow of fluid through the orifice. In order to simulate this action, this study proposes to add a frictional model serial to the Maxwell Model for simulating a small damper parallel to the frictional model (Fig. 1). The simulation results are compared with the experimental results to verify the validity of the derived mathematical model on simulating infinite relief force, occurrence of relief on dampers, and the behaviour of energy elimination in which viscous damping and relief take place at the same time. The real seismic reduction performance of this proposed damper operated under different relief forces is investigated with the shaking table test under the excitation of El Centro earthquake with various peak ground accelerations to verify the seismic proof capability of this proposed damper. Results of mathematical modelling are compared with the lab results on structural displacement and acceleration reduction variation obtained with the shaking table to ensure the accuracy of the mathematical model for field applications. The math model is 


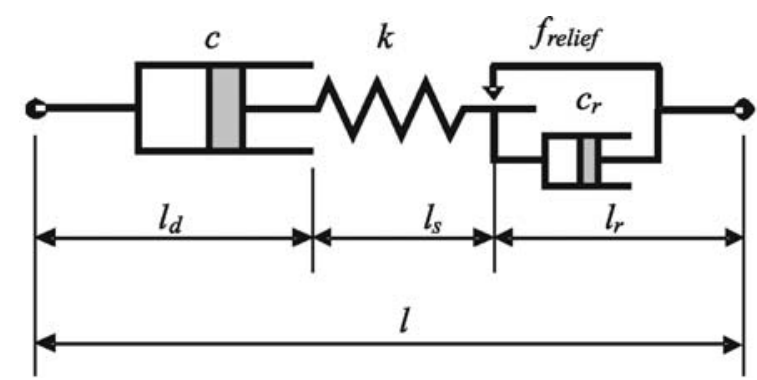

Fig. 1. The Maxwell Model with the addition of a frictional model serial to simulate the proposed new oil-pressure damper

also used to analyse the structural displacement and acceleration reduction effects for structure added with VDHD under excitation of El Centro earthquake record with various peak ground acceleration from $0.05 \mathrm{G}$ to $1.0 \mathrm{G}$ in order to investigate the influence of various relief forces of the propose damper.

\section{Elements and Energy Dissipation Behaviour of Velocity Dependent Hydraulic Damper, VDHD}

\subsection{Elements of VDHD}

The passive energy dissipation behaviour of the Velocity Dependent Hydraulic Damper (VDHD as proposed in this research is mainly generated by controlling the relieve valve and the throttle valve of the hydraulic damper. The relief valve can limit the maximum pressure of the hydraulic cylinder. The throttle valve that is connected in parallel with the relief oil path is a small circulating hole that can be adjusted externally by hand. The pressure of VDHD drops when the viscous oil is flowing in the throttle valve. Normally this pressure drop is proportional to the flow rate by first-order to quadratic equations. By adding this parallel connection, the throttle valve can generate automatic homing function in response to damper vibration. However, such that interdependent velocities can be automatically generated the natural manual system. Major components of the proposed VDHD are shown in Fig. 2 with their functions briefly described as follows:

A. Hydraulic Jack: The hydraulic jack is the main force transmission structure of the damper. It is connected by two hinges to the structural body and the bracing. The action force of the hydraulic jack equals to the product variance between the two sides pressure of the piston and the piston area. The pressure change causes the force exertion to change.

B. Relief Valve: The relief valve can maintain a certain value of oil pressure in the oil loop. If a set pressure is exceeded, this valve will be automatically opened to let oil to pass through resulting in pressure reduction.

C. Throttle Valve: The throttle valve controls the oil flow rate by changing the cross-section of the oil pressure channel.

D. Check Valve: The check valve allows the moving oil to flow in a single direction and in this way; it can master the oil path easily.

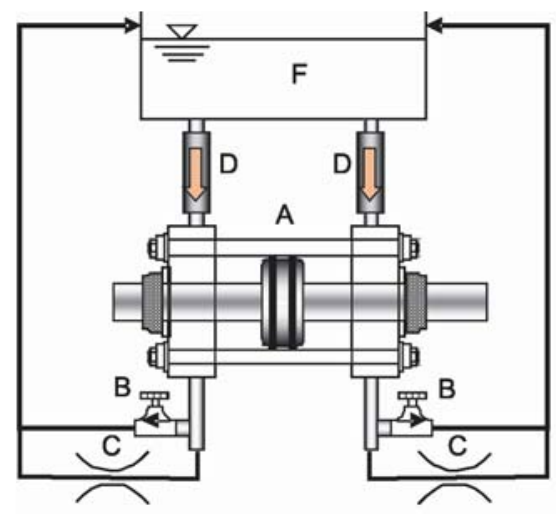

A. Hydraulicjack

B. Relief valves

C. Throttle valves

D. Check valves

Fig. 2. The structure of VDHD

\subsection{Element test of VDHD}

This research has planned for a series of element tests for investigating the seismic proof feasibility of the proposed VDHD. The deformation behaviour of the bracing in the element test and the inter-function between the expansion and contraction behaviour of the damper are important factors to affect the feasibility of VDHD. Therefore, a soft spring is added to the structure to simulate the bracing element during the element test of this research. The assemblage of VDHD and structure is shown in Fig. 3: the test structure is shown in Figs. 4 and 5.

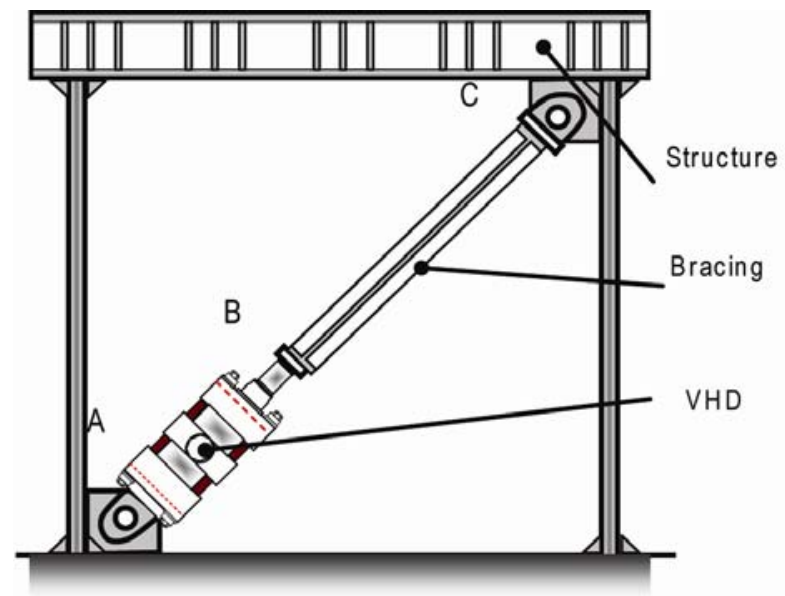

Fig. 3. The assemblage of VHD and structure

\section{Numerical analysis}

\subsection{Numerical modelling}

The aperture of the relief valve is not fixed; therefore, strictly speaking, the damping coefficient is not a constant value. When deriving the mathematical analysis model, suppose that the variation of the length $l_{r}$ in the frictional model (Fig. 1) is $u_{r}$; based on a balance, the damping force is supposed as

$$
F=f_{\text {relief }}+c_{r} \dot{u}_{r}
$$

where: $f_{\text {relief }}-$ relief force of damper, unit $-k N ; c_{r}-$ damping coefficient of relief valve; $\dot{u}_{r}-$ deformation rate of elongation of relief valve model, unit $-\mathrm{m} / \mathrm{sec}$. 


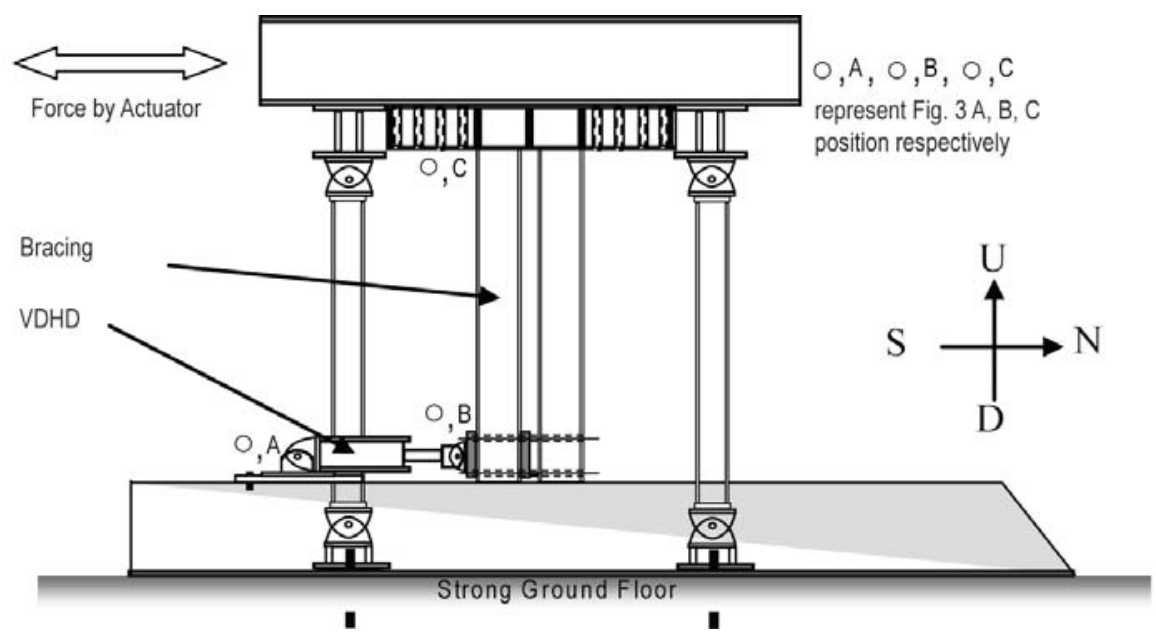

Fig. 4. The experimental test of shear building

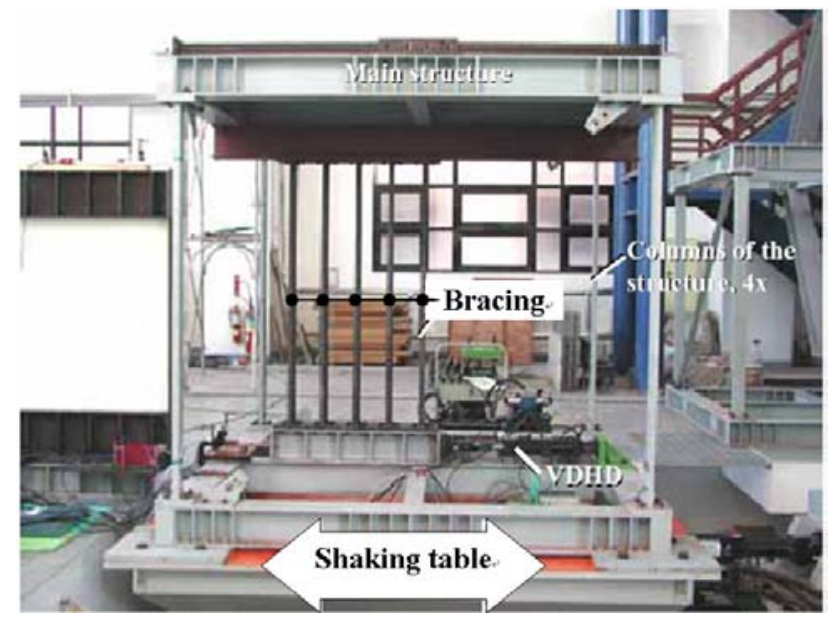

Fig. 5. The dynamic test for share building added with VDHD

If the relief of a damper does not occur, the internal force of the element is:

$$
\dot{u}=\dot{u}_{d}+\dot{u}_{s}+\dot{u}_{r},
$$

where: $\dot{u}_{d}-$ deformation rate of elongation of viscous damper $\left(u_{d}=l_{d}\right.$, shown in Fig. 1$), \dot{u}_{d}=F / c$, unit: $m / \mathrm{sec} ; \quad \dot{u}_{s}$ - deformation rate of elongation of $\operatorname{spring}\left(u_{s}=l_{s}\right.$, shown in Fig. 1$), \dot{u}_{s}=\dot{F} / k$, unit: $\mathrm{m} / \mathrm{sec}$.

From equation (1), the deformation velocity of frictional model can be derived as:

$$
\dot{u}_{r}=\frac{F-f_{\text {relief }}}{c_{r}} .
$$

Substituting equation (3) into equation (2), the following equation can be acquired:

$$
\frac{1}{k} \dot{F}+\frac{c+c_{r}}{c c_{r}} F=\dot{u}+\frac{f_{\text {relief }}}{c_{r}} .
$$

Defined generalized stiffness, damping coefficient and element velocity expressed as follows:

$$
\bar{k}=k \text {, }
$$

$$
\begin{gathered}
\bar{c}=\frac{c c_{r}}{c+c_{r}}, \\
\dot{\bar{u}}=\dot{u}+\frac{f_{\text {relief }}}{c_{r}} .
\end{gathered}
$$

Therefore, the governing equation under open situation of relief valve is shown as:

$$
\frac{1}{\bar{k}} \dot{F}+\frac{1}{\bar{c}} F=\dot{\bar{u}} .
$$

Thus, solving the continuous solution and discrete solution, the systematic constants can be obtained as follows:

$$
\begin{gathered}
\bar{D}=e^{-\frac{\bar{k}}{\bar{c}} \Delta T}, \\
\bar{E}=(1-\bar{D})\left(1+\frac{\bar{c}^{2}}{\bar{k} \Delta T}\right)-\bar{c}, \\
\bar{G}=-(1-\bar{D}) \frac{\bar{c}^{2}}{\bar{k} \Delta T}+\bar{c} .
\end{gathered}
$$

The discrete solution is shown as:

$$
F_{1}=\bar{D} F_{0}+\bar{E} \dot{\bar{u}}_{0}+\bar{G} \dot{\bar{u}}_{1} \text {. }
$$

When damping occurs without the relief, the internal force of component is:

$$
F_{1}=D F_{0}+E \dot{u}_{0}+G \dot{u}_{1},
$$

where: $D$ - initial coefficient of discrete solution, $D=e^{-\frac{k}{c} \Delta T} ; E-$ initial velocity coefficient of discrete solution, $E=(1-D)\left(1+\frac{c^{2}}{k \Delta T}\right)-c ; G-$ end velocity coefficient of discrete solution, $G=-(1-D) \frac{c^{2}}{k \Delta T}+c$.

Equation (12) is a discrete solution under the condition of relief, and equation (13) is suitable for the discrete solution without the relief. The practical analytical procedures are as follows: 
1) If $\operatorname{abs}\left(F_{0}\right) \leq f_{\text {relief }}$, the equation (13) is applied to evaluate the damping force $F_{1}$ of next step;

2) If $a b s\left(F_{0}\right)>f_{\text {relief }}$, the equation (12) is applied to evaluate the damping force $F_{1}$ of next step.

\subsection{Friction force between shaft and packing}

An inseparable grease seal and an O-shaped ring installed between the oil cylinder, the axis, and the piston in order to prevent the pressurized pressure oil from leaking will cause certain friction during the damping process. This friction can be ignored if the damping force is strong; however, for the integrity of the theory, it will still be taken into consideration in the math model. The friction is paralleled with the elements stated in the prior sections such that only the friction value needs to be adjusted by $F_{1}$, which is derived from equation (13) or equation (12), according to the damper's exercise direction as:

$$
F_{1}^{*}= \begin{cases}F_{1}+f_{f} & \dot{u}_{1}>0, \\ F_{1} & \dot{u}_{1}=0, \\ F_{1}-f_{f} & \dot{u}_{1}<0,\end{cases}
$$

where: $F_{1}^{*}$ - total damping force; $f_{f}$ - frictional force.

The experiment result shows that the friction $f_{f}$ is not a constant. But, if the damping force is relatively bigger than the friction, it is acceptable to ignore the variations in $f_{f}$.

If the varieties of the expansion and contraction directions of the damper are considered, a complete analysis is supposed to include two sets of systematic constants, defined as $D, E$ and $G$, initial coefficient of discrete solution, initial velocity coefficient of discrete solution and end velocity coefficient of discrete solution respectively, and sets of generalized systematic constants, as defined at equation (9) to equation (11). Every systematic constant in the procedure of the analysis will be determined in the previous procedure, and it is supposed that this mechanical property will only be used in this step. The analytical procedures constructed in the dynamic analysis program are shown in Fig. 6.

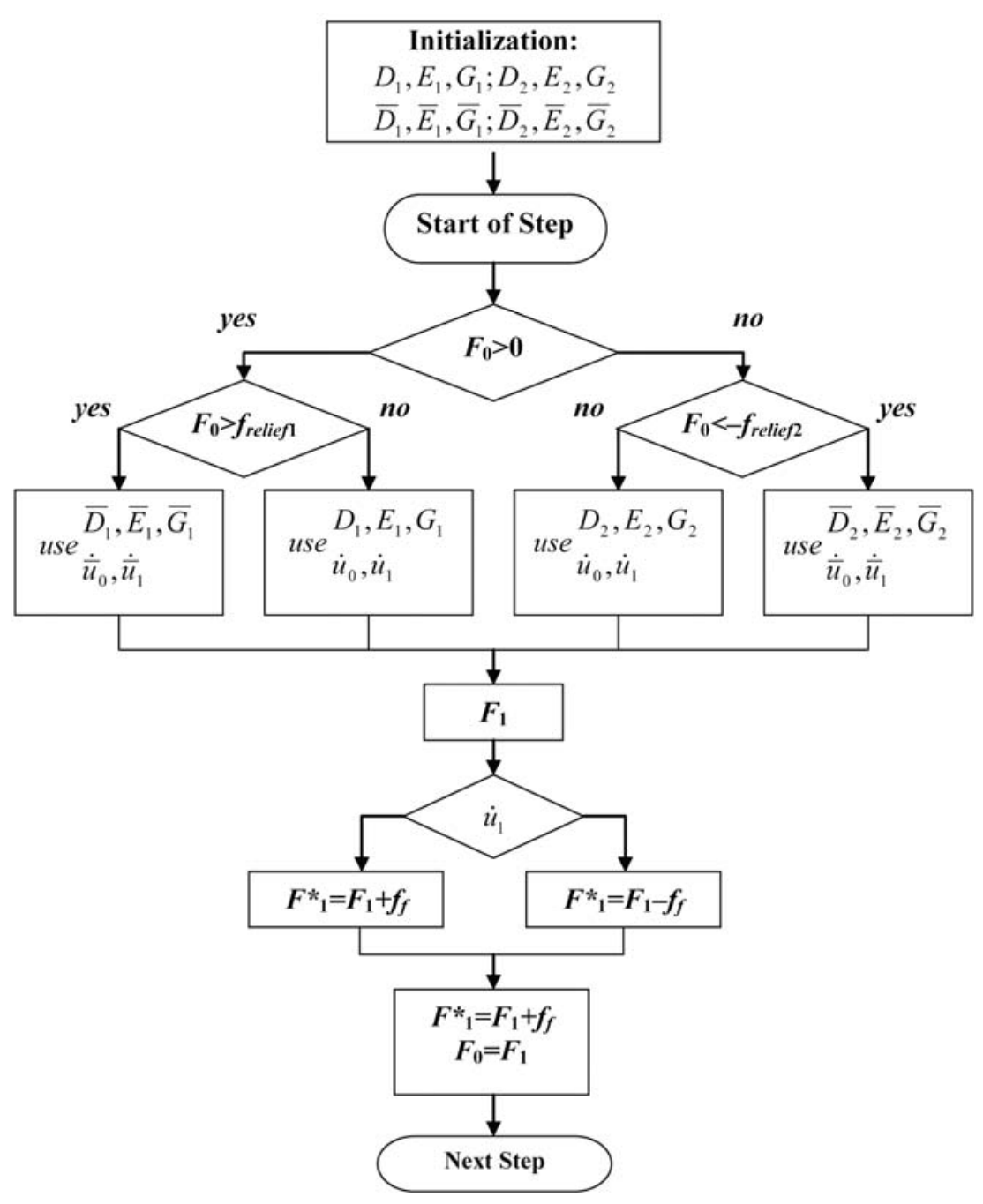

Fig. 6. Analysis flow chart 


\section{Experimental verification}

In order to verify the authenticity of the above-mentioned hypothesis, the element test will be conducted at $20 \mathrm{~mm}$ amplitude and $0.2 \mathrm{~Hz}$ RD frequency.

\subsection{Comparison of experimental results and simulation results}

\subsubsection{The relief force of the damper is infinite}

In this situation, the energy dissipation performance of VDHD is similar to that of viscous damper as seen by the similar ellipse-like relationship between force and displacement for both as shown in Fig. 7. Especially, the relationship between force and velocity relation is difficult to simulate, however, the proposed mathematical model can accurately simulate this energy dissipation performance as shown Fig. 8.

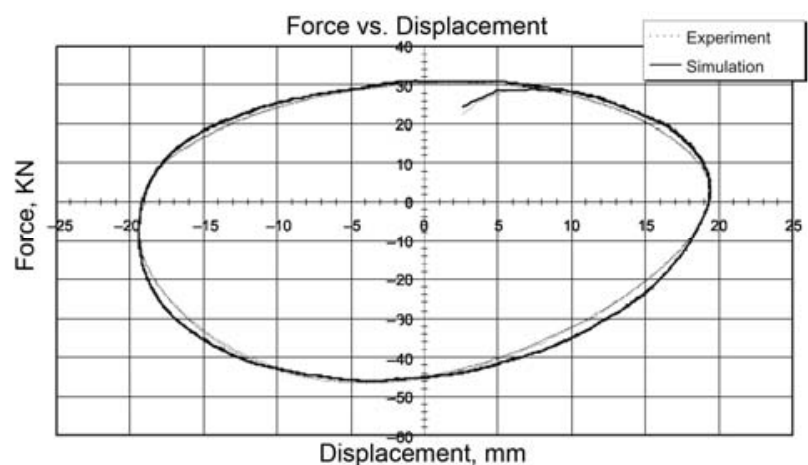

Fig. 7. The comparison between the experimental and simulation results for the relationship of force and displacement with infinite relief force

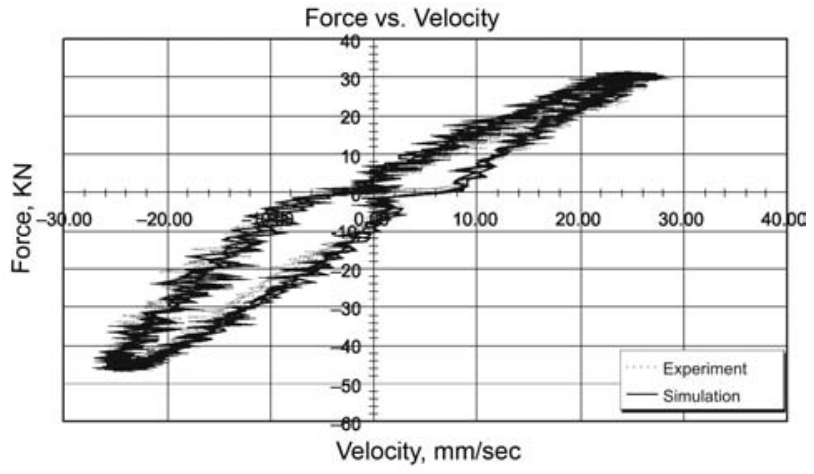

Fig. 8. The comparison between the experimental and simulation results for the relationship of force and velocity with infinite relief force

\subsubsection{Relief of a damper occurs, and the damping coefficient before the relief is infinite}

When relief phenomenon of VDHD occurs, the damping coefficient is infinite and the energy dissipation capability of VDHD reaches the limit value. The energy dissipation area of force and displacement relation performs square is shown in Fig. 4. This mathematical model as derived in the above sections can still accurately simulate these energy dissipation performances of force-displacement and force-velocity as illustrated in Figs. 9 and 10.

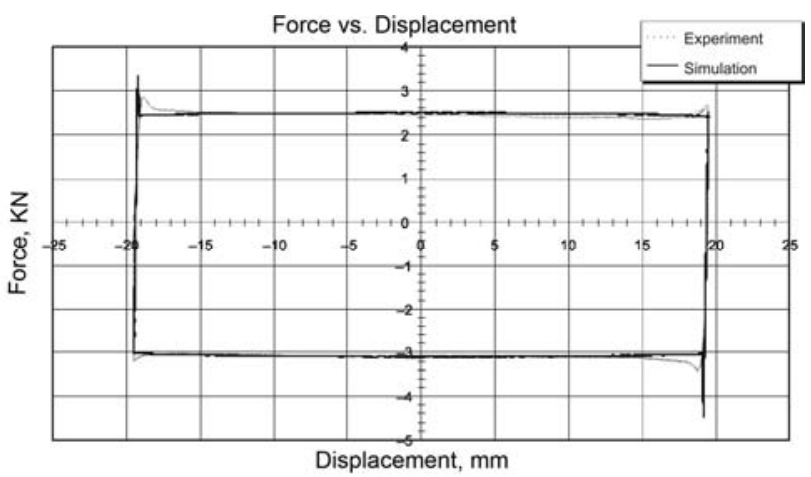

Fig. 9. The comparison between the experimental results and simulation results for the relationship of force and displacement when relief of the damper occurs with the infinite damping coefficient before the relief

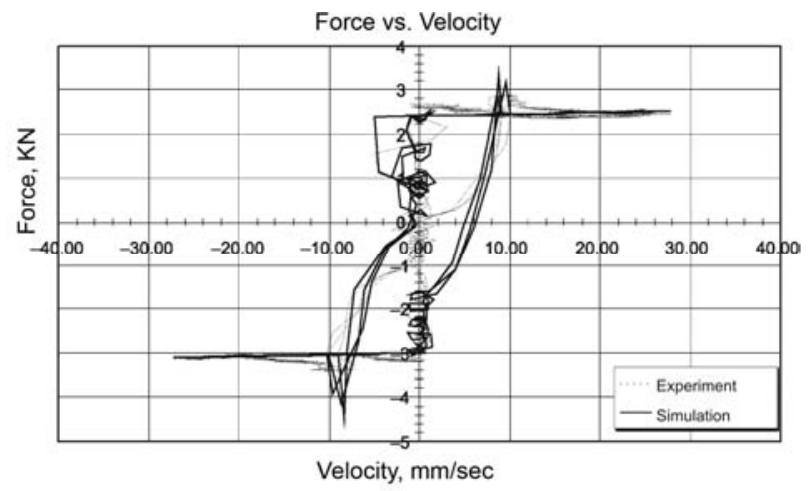

Fig. 10. The comparison between the experimental and simulation results for the relationship of force and velocity when relief of the damper occurs with infinite damping coefficient before the relief

\subsubsection{Relief and throttling take place at the same time}

When the relief and throttling phenomena occur simultaneously, the deformation quantity of VDHD reaches an extremity of the designed deformation. The forcedisplacement and force-velocity relations depend on the vibration frequency of external forces, i.e. seismic force and wind load. The additional deformation can be dissipated by the bracing stiffness of bracing and structure ductility. In experimental tests, the amplitude is defined as $20 \mathrm{~mm}$ and the damping frequency changes from 0.1 to $1.8 \mathrm{~Hz}$. The simulated results show that regardless of force-displacement or force-velocity relations, the proposed model can accurately simulate these energy dissipation behaviours as shown in Figs. 11-14.

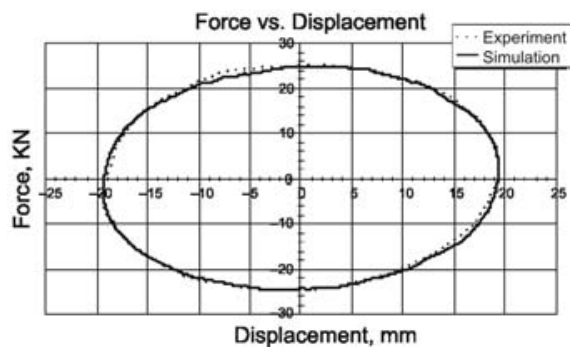

Fig. 11a. Amplitude $=20 \mathrm{~mm}$, Freq. $=0.1 \mathrm{~Hz}$ 


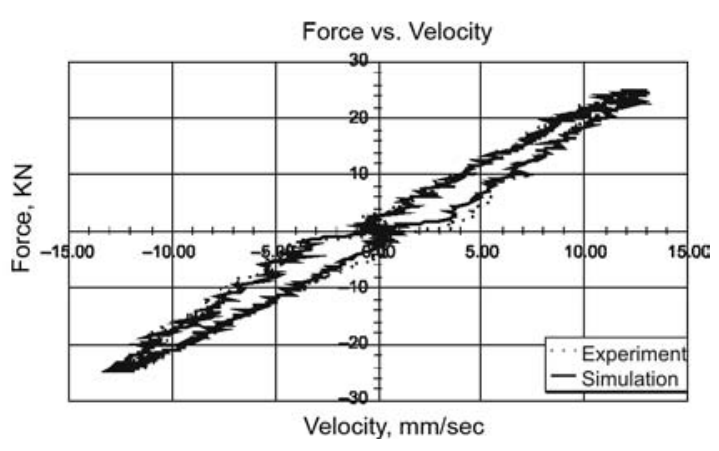

Fig. 11b. Amplitude $=20 \mathrm{~mm}$, Freq. $=0.1 \mathrm{~Hz}$

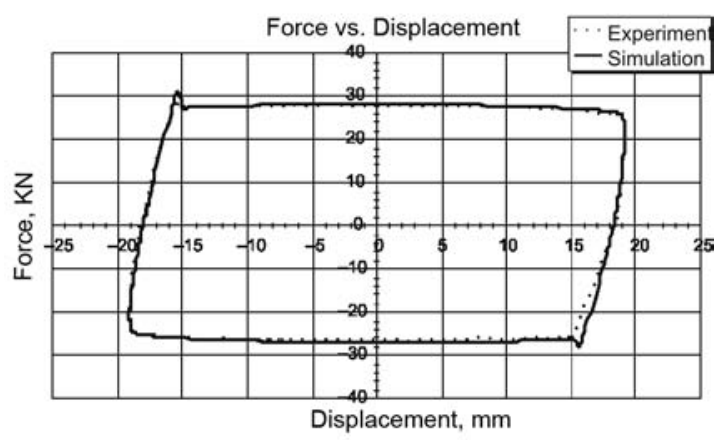

Fig. 12a. Amplitude $=20 \mathrm{~mm}$, Freq. $=0.6 \mathrm{~Hz}$

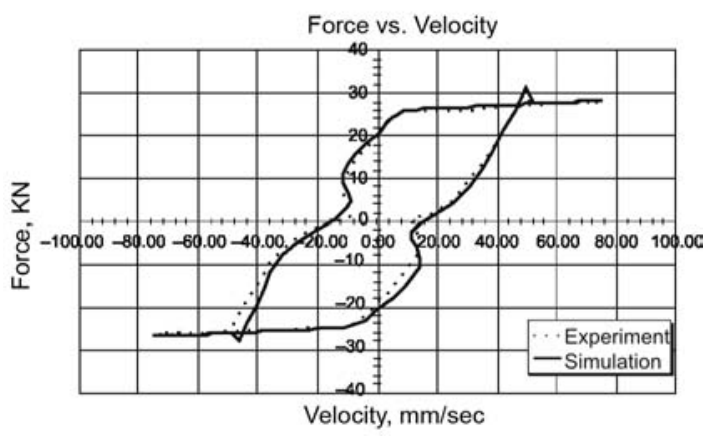

Fig. 12b. Amplitude $=20 \mathrm{~mm}$, Freq. $=0.6 \mathrm{~Hz}$

\section{Shaking table tests}

In order to verify the seismic reduction performance of this proposed damper, three tested structures are designed and used in shaking table tests including type A, a steel frame without bracing, type B a frame with bracing and type $\mathrm{C}$, structure with bracing and VDHD.

\subsection{System identification for tested structures}

The forced displacement White Noise is used to identify the natural frequencies of these three test structures. A typical displacement signal for shaking table tests is shown in Fig. 15. The acceleration response functions for these three tested structures are shown in Fig. 16.

All dynamic properties are suitable for analyzing all earthquake records and various peak ground accelerations for type A and B tested structure in accordance with the linear characteristics of these two frames. The frequency response functions of the structure with VDHD (Type C) are related to seismic reaction records and vibration ranks

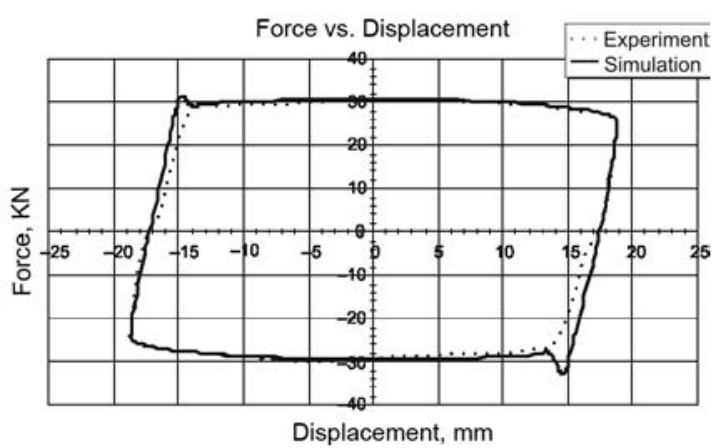

Fig. 13a. Amplitude $=20 \mathrm{~mm}$, Freq. $=1.2 \mathrm{~Hz}$

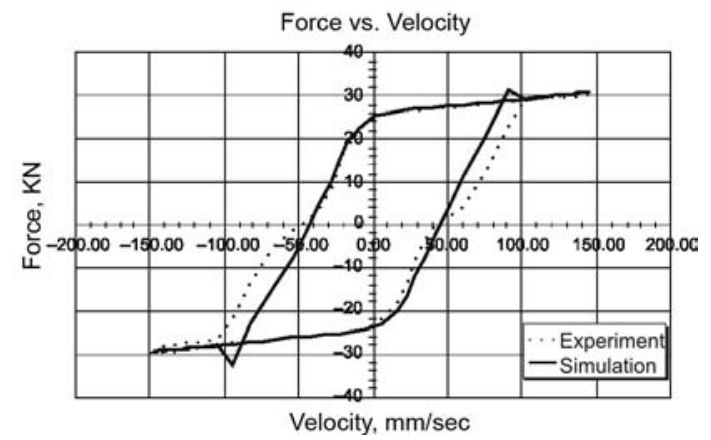

Fig. 13b. Amplitude $=20 \mathrm{~mm}$, Freq. $=1.2 \mathrm{~Hz}$

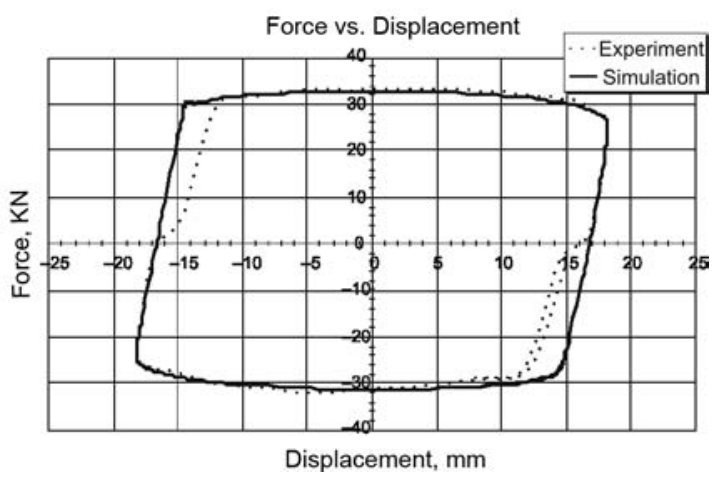

Fig. 14a. Amplitude $=20 \mathrm{~mm}$, Freq. $=1.8 \mathrm{~Hz}$

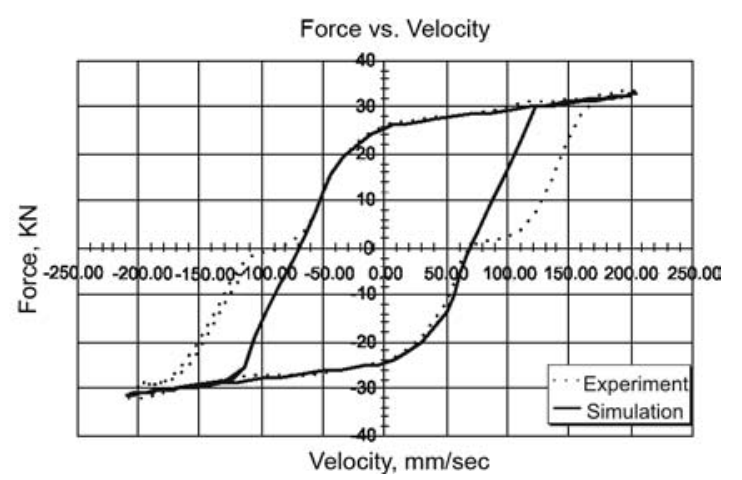

Fig. 14b. Amplitude $=20 \mathrm{~mm}$, Freq. $=1.8 \mathrm{~Hz}$

according to the non-linear behaviour of VDHD. Therefore, the dynamic change conditions of type $\mathrm{C}$ structure are identified and investigated under the excitation of the El Centro earthquake records with various peak ground accelerations. The average acceleration frequency response functions of type $\mathrm{C}$ frame with different forces of 


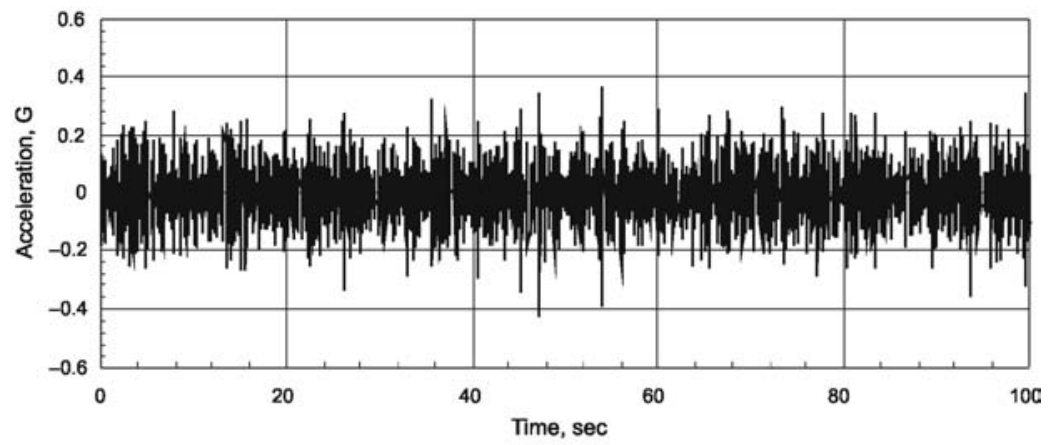

Fig. 15. Time history of the acceleration signal for system identification for tested structures

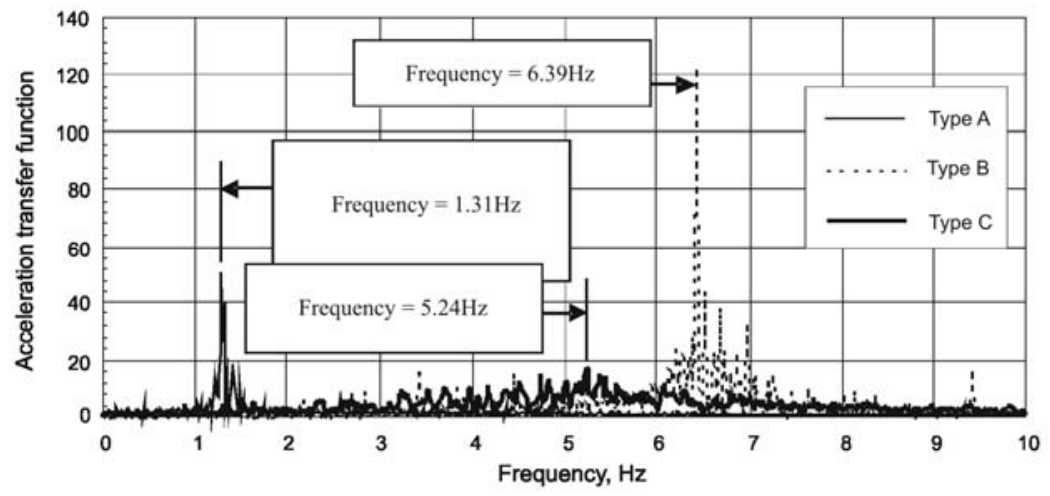

Fig. 16. Acceleration frequency responses functions for tested structures

relief valve are shown in Fig. 17. The system identification results of this tested frame that are calculated based on the square root method reveal that for type $\mathrm{C}$ frame, main natural frequencies are between $5.24 \mathrm{~Hz}$ and $5.43 \mathrm{~Hz}$ while the resulting damping ratio lies in between 0.026 and 0.029 . All system identification results of natural frequencies and damping ratios for these three different tested structures are listed in Table 1.

Table 1. Structural identification results of shaking table tests

\begin{tabular}{c|c|c|c}
\hline Structure type & Type A & Type B & Type C (average) \\
\hline Frequency, Hz & 1.31 & 6.39 & 5.24 \\
\hline Damping ratio & 0.006 & 0.004 & 0.027 \\
\hline Mass, kg & 4901 & 4901 & 4901 \\
\hline
\end{tabular}

\subsection{Test results of seismic reduction performance for VDHD}

In order to verify the seismic reduction performance of VDHD, the El Centro earthquake record that contains higher frequency quantity of impulse to structure is used to test and verify the seismic proof capability of the proposed damper in the shaking table test. The maximum output force of this damper can be adjusted by regulating the relief valve. In coordination with the dead load of shaking table structure, i.e. $4901 \mathrm{~kg}$, the output and input power of relief force of VDHD is set measure to $5 \mathrm{kN}$, $10 \mathrm{kN}$ and $15 \mathrm{kN}$. To probe the displacement and acceleration reduction percentage of the structure equipped with VDHD is subject to different relief forces under the peak ground accelerations of El Centro earthquake varying from $0.05 \mathrm{G}$ to $0.37 \mathrm{G}$. The seismic reduction percent- age of displacement and acceleration respectively are defined as follows to verify the seismic proof performance of the proposed damper used in the tested structure.

Displacement reduction percentage

$$
=\frac{M D O-M D C}{M D O} \times 100 \% \text {. }
$$

Acceleration reduction percentage

$$
=\frac{M R O-M R A}{M R O} \times 100 \%,
$$

where:

$M D O$ is the maximum relative displacement of original structure without VDHD;

$M D C$ is the maximum relative displacement of structure added with VDHD;

$M R O$ is the maximum absolute acceleration of original structure without VDHD;

$M R A$ is the maximum absolute acceleration of structure added with VDHD.

Figs. 18 and 19 indicate variations of structural displacement and structural acceleration reduction percentage under the condition of VDHD operated at different relief forces and excitation levels of El Centro earthquake record using various PGA (peak ground acceleration).

Fig. 18 indicates the various seismic reduction effects on structural displacement at various peak ground acceleration levels. When the relief force is greater than $10 \mathrm{kN}$, all structural displacement reduction percentages exceed $95 \%$ under the excitation of El Centro earthquake with different PGA. Nevertheless, the structural displa- 
cement reduction percentage obviously decreases when PGA is greater than $0.15 \mathrm{G}$ for the $5-\mathrm{kN}$ relief force. This phenomenon reveals that the $5 \mathrm{kN}$ relief force of VDHD is insufficient for the vibration characteristic with high frequency quantity earthquake. But, regardless of what the relief force is, all the structural displacement reduction percentage attain $78 \%$ and above for various peak ground accelerations.

Fig. 19 shows that the influence of relief force on acceleration reduction percentage is more complex than that on structural displacement reduction effect. The less relief force of VDHD can quickly react to diminish the structural acceleration response along with the increase of PGA from around $0.15 \mathrm{G}$ to $0.35 \mathrm{G}$. But, the $10 \mathrm{kN}$ relief force of VDHD causes higher structural acceleration reduction effect for PGA level up to $0.35 \mathrm{G}$. Fig. 19 indicates negative structural acceleration reduction percentages of shaking table test for type B test frame because that the El Centro earthquake contains high frequency quantity. When the peak ground acceleration increase, the acceleration reduction effects of VDHD are raised.

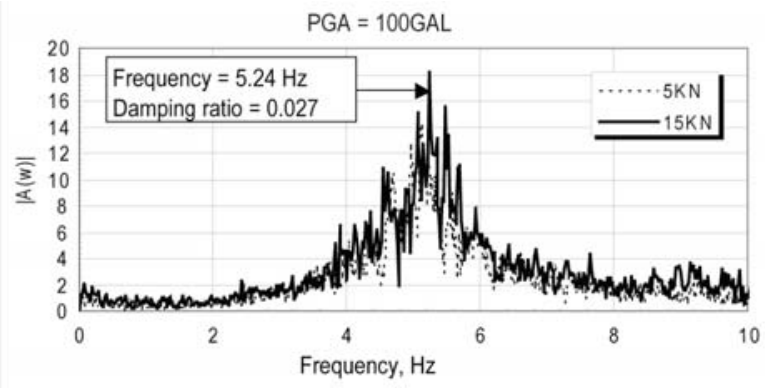

(a) $\mathrm{PGA}=100 \mathrm{GAL}$

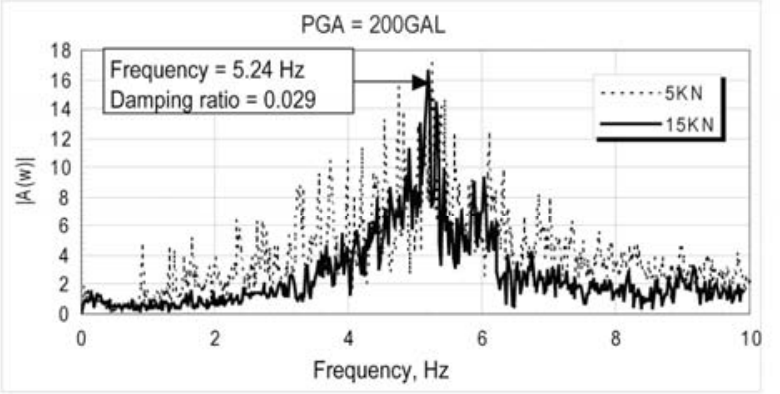

(b) $\mathrm{PGA}=200 \mathrm{GAL}$

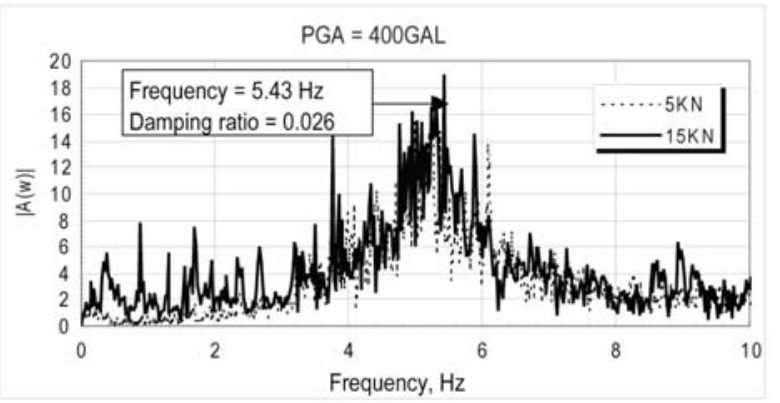

(c) $\mathrm{PGA}=400 \mathrm{GAL}$

Fig. 17. Natural frequency and damping ratio response of type $\mathrm{C}$ tested frame under excitation of El Centro earthquake with various PGA

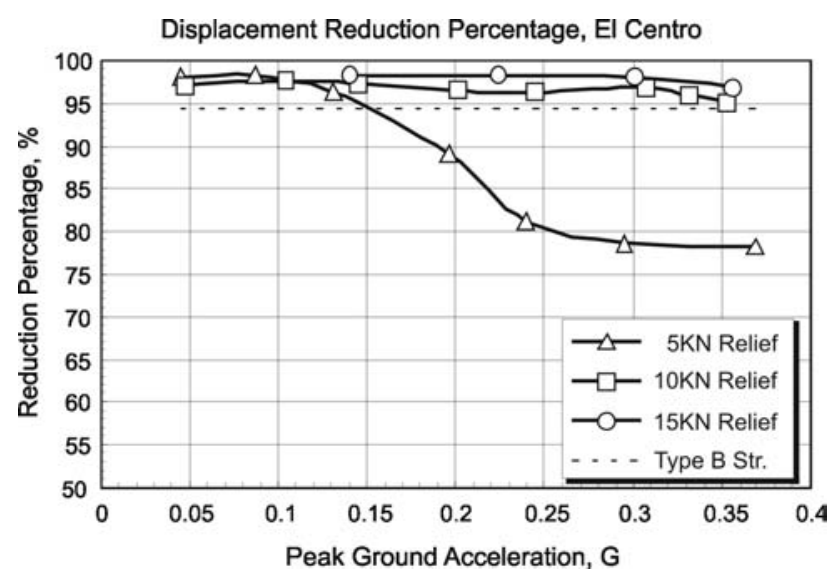

Fig. 18. The variation of structural displacement reduction percentage under the condition of VDHD with different relief pressure and El Centro earthquake with various PGA

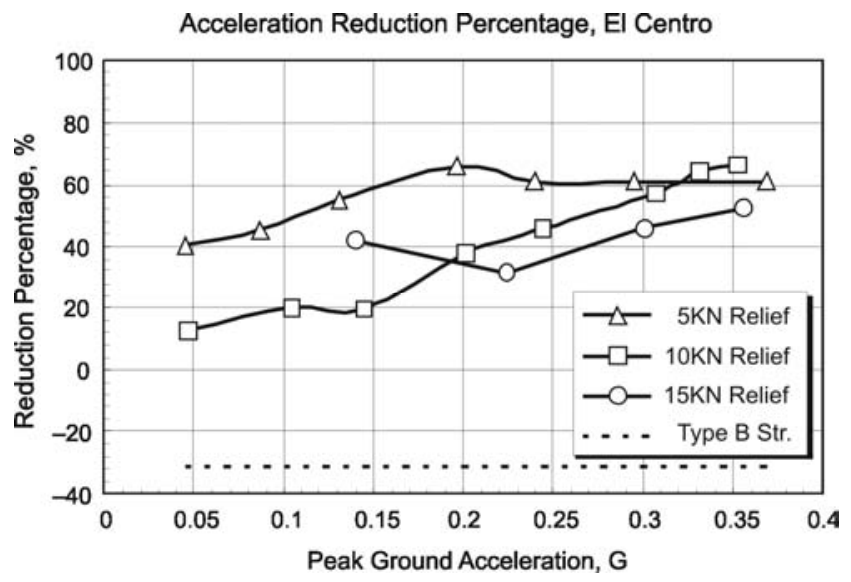

Fig. 19. The variation of structural acceleration reduction percentage under the condition of VDHD with different relief pressure and El Centro earthquake with various PGA

\section{Simulation analysis results}

The beneficial influence of various relief force of VDHD is investigated by using the proposed mathematical modelling to analyse the structural displacement and acceleration reduction effects for the structure under equipped with the proposed damper. Fig. 20 and 21 show the simulated displacement and acceleration reduction percentage results under the condition of VDHD with different relief forces and El Centro earthquake with various PGAs.

The comparison between Fig. 18 and Fig. 21 reveal that the simulated displacement and acceleration percentage reduction curve agrees have similar changing tendency as the experimental results. Fig. 20 shows that all the seismic displacement reduction percentages are greater than $70 \%$ structural displacement reduction percentage. Especially, higher relief force of VDHD causes more structural displacement reduction percentage. Therefore, if the structural displacement reduction is a main consideration, the relief force of VDHD should be increased. Fig. 20 indicates that acceleration reduction percentage is not related to relief force of VDHD under the smaller PGA excitation. When the PGA excitation is greater than $0.4 \mathrm{G}$, the acceleration reduction percentage are up to 
$60 \%$. Thus, if the structural acceleration reductions also need to be considered, smaller absolute acceleration would be happened caused by smaller relief force of VDHD under small-scale earthquake and by larger relief force of VDHD under middle-scale and large-scale earthquake.

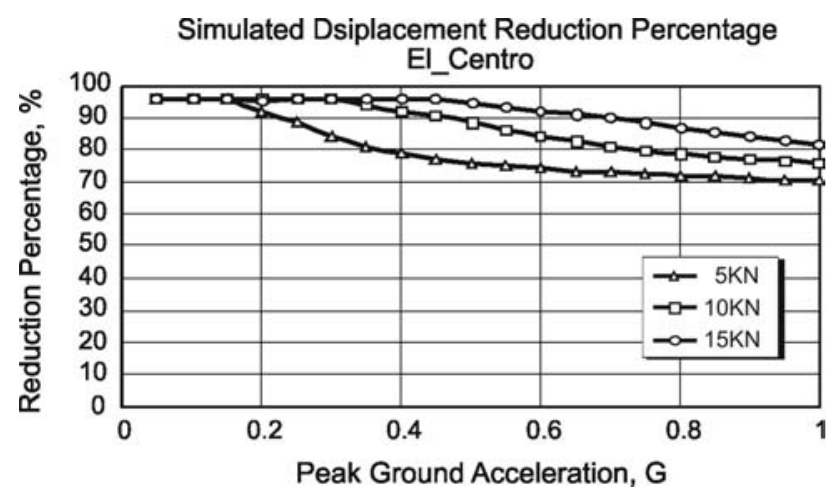

Fig. 20. The simulated results on structural displacement reduction percentage under the condition of VDHD with different relief forces and El Centro earthquake with various PGAs

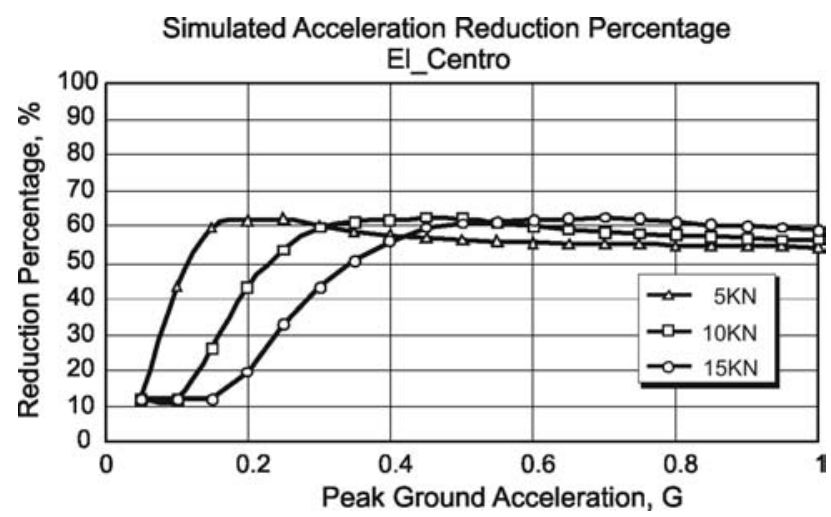

Fig. 21. The simulated results on structural acceleration reduction percentage under the condition of VDHD with different relief forces and El Centro earthquake with various PGAs

\section{Conclusions}

Results of both numerical analyses and experiments obtained in this study show that the mathematical model can accurately simulate the relation of force and drift and the relation of force and velocity during the process of damping energy elimination. Regardless of the phenomena of relief force of the damper is infinite or the relief of a damper takes place but the damping coefficient is infinite before it occurs or the friction is paralleled with viscous damping, this mathematical model can simulate them well. Besides, when both damping coefficients (Damper $c_{1}$ and Damper $c_{2}$ ) and relief force are finite when viscous damping and relief take place simultaneously in the experiment, no matter how the damping expansion frequency changes, the mathematical analysis model will accurately simulate the relationships among the force, drift, and velocity during the process of damping energy elimination in spite of how the damping expansion frequency changes. Therefore, the analytical model pro- posed in this study can be applied to simulate the relation of the damping force and the axial velocity of the damper.

Both the shaking table test results and the simulation analysis results are examined to verify the seismic capacity of the proposed VDHD under the excitation of El Centro earthquake record with various peak ground accelerations. The energy-dissipating capability of the damper has been verified with the experimental results. The structural response reduction effects of VDHD can be summarized as: 1) All structural displacement reduction percentages exceed $78 \%$ under middle-scale and small-scale earthquake; they attain $70 \%$ structural displacement reduction percentages under large-scale earthquake regardless of the relief force of VDHD. The results demonstrate that this device performs very well on displacement control with a variety of ground magnitudes. 2) The structural acceleration reduction percentage diminishes $56 \%$ under the excitation of PGA more than $0.4 \mathrm{G}$. 3) The performance of the proposed VDHD has been shown to achieve the objective as a displacement control structure. The relief force should be set from $20 \%$ to $30 \%$ dead load of the structure that conforms to the design criteria of Taiwan building code.

The VDHD functions as an energy absorber to dissipate the mechanical energy in the structure and convert this energy as potential energy to resist the structural movement. It diminishes the displacement and acceleration of the structure caused by earthquake excitation. Both the laboratory test and simulation results demonstrate that this device performs well for structural control under various magnitudes of the earthquake being examined.

\section{Acknowledgement}

The National Science Council of Taiwan, R.O.C. supported this research through grant No. NSC 97-2626-M167-001. These supports are gratefully acknowledged

\section{References}

Dyke, S. J.; Spencer, B. F. Jr.; Sain, M. K.; Carlson, J. D. 1998. An experimental study of MR dampers for seismic protection, Smart Materials and Structures 7(5): 693-703. doi:10.1088/0964-1726/7/5/012

Kim, J. W.; Cho, Y. H.; Choi, H. J.; Lee, H. G.; Choi, S. B. 2002. Electrorheological semi-active damper: Polyaniline based ER system, Journal of Intelligent Material Systems and Structures 13(7-8): 509-513.

doi:10.1106/104538902028669

Kobori, T.; Takahashi, M.; Ishibashi, T.; Niwa, N.; Tagami, J.; Midorikawa, H. 1999. Development of Active Variable Damping (AVD) System for structural response control in large earthquakes, in Annual Report, Kajima Technical Research Institute, Kajima Corporation 47: 167-172.

Kurata, K.; Kobori, T.; Takahashi, M.; Ishibashi, T.; Niwa, N.; Tagami, J.; Midorikawa, H. 2000. Forced Vibration Test of a Building with Semi-Active Damper System, Earthquake Engineering and Structural Dynamics 29: 629-645. doi:10.1002/(SICI)1096-9845(200005)29:5< 629::AID-EQE928>3.0.CO;2-9

Kurata, N.; Kobori, T.; Takahashi, M.; Niwa, N.; Midoridawa, H. 1999. Actual Seismic Response Controlled Building 
with Semi-Active Damper System, Earthquake Engineering and Structural Dynamics 28: 1427-1447.

doi:10.1002/(SICI)1096-9845(199911)28:11<1427::AIDEQE876>3.0.CO;2-\#

Lee, D.; Taylor, D. P. 2001. Viscous damper development and future trends, The Structural Design of Tall Buildings 10: 311-320. doi:10.1002/tal.188

Loh, C. H.; Lynch, J. P.; Lu, K.C.; Wang, Y.; Chang, C. M.; Lin, P.Y.; Yeh, T. H. 2007. Experimental verification of a wireless sensing and control system for structural control using MR dampers, Earthquake Engineering and Structural Dynamics 36(10): 1303-1328. doi:10.1002/eqe.682

Plummer, A. R. 2006. Control techniques for structural testing: a review, in Proceedings of the Institution of Mechanical Engineers, Part I: Journal of Systems and Control Engineering 221: 139-169.

Pranoto, T.; Nagaya, K.; Hosoda, A. 2004. Vibration suppression of plate using linear MR fluid passive damper, Journal of Sound and Vibration 276(3-5): 919-932. doi:10.1016/j.jsv.2003.08.019

Rodellar, J. 2004. A technical overview of European research in structural control and health monitoring, in Proceeding of the $4^{\text {th }}$ International Workshop on Structural Control, 1828.

Shih, M. H.; Sung, W. P. 2004. The Energy Dissipation Behavior of Displacement Dependent Semi-Active Hydraulic Damper, Journal of Structural Mechanics and Earthquake Engineering 21(2): 121s-129s. doi:10.2208/jsceseee.21.121s

Shih, M. H.; Sung, W. P.; Go, C. G. 2002. Development of Accumulated Semi-Active Hydraulic Damper, Experimental Techniques 26(5): 29-32. doi:10.1111/j.1747-1567.2002.tb00081.x

Shih, M. H.; Sung, W. P.; Go, C. G. 2003. A Design Concept with a Displacement Dependent Semi-Active Hydraulic Damper for Energy Dissipation, Experimental Techniques 27(6): 53-56. doi:10.1111/j.1747-1567.2003.tb00139.x

Shih, M. H.; Sung, W.P. 2006. Development and Seismic Reduction Performance of Velocity and Displacement Dependent Hydraulic Damper, Experimental Techniques 30(3): 41-45. doi:10.1111/j.1747-1567.2006.00041.x
Shulman, Z. P.; Korobko, E. V.; Levin, M. L.; Binshtok, A. E.; Bilyk, V. A.; Yanovsky, Yu. G. 2006. Energy dissipation in electrorheological damping devices, Journal of Intelligent Material Systems and Structures 17(4): 315-320. doi:10.1177/1045389X06054580

Song, H. J.; Choi, S. B.; Kim, J. H.; Kim, K. S. 2002. Performance evaluation of ER shock damper subjected to impulse excitation, Journal of Intelligent Material Systems and Structures 13(10): 625-628. doi:10.1177/1045389X02013010003

Soong, T. T.; Cimellaro, G. P. 2008. Future Directions in Structural control, Structural Control and Health Monitoring 16(1): 7-16. doi:10.1002/stc.291

Soong, T. T.; Spencer, Jr. B. F. 2002. Supplemental energy dissipation: state-of-the-art and state-of-the-practice, Engineering Structures 24: 243-259. doi:10.1016/S0141-0296(01)00092-X

Su, Y. X.; Duan, B. Y.; Wei, Q.; Nan, R. D.; Peng, B. 2003. The wind-induced vibration control of feed supporting system for large spherical radio telescope using electrorheological damper, Mechatronics 13(2): 95-110. doi:10.1016/S0957-4158(01)00042-3

Wang, J.; Meng, G. 2005. Study of the vibration control of a rotor system using a magnetorheological fluid damper, Journal of Vibration and Control 11(2): 263-276. doi:10.1177/1077546305049481

Wereley, N. M. 2008. Nondimensional herschel-bulkley analysis of magnetorheological and electrorheological dampers, Journal of Intelligent Material Systems and Structures 19(3): 257-268. doi:10.1177/1045389X07088107

Xu, L. H.; Li, Z. X. 2008. Semi-active multi-step predictive control of structures using MR dampers, Earthquake Engineering and Structural Dynamics 37(12): 1435-1448. doi:10.1002/eqe.822

Xu, Y. X., Qu, W. L. and Ko, J. M., 2000. Seismic Response Control of Frame Structures Using Magnetorheological/Electrorheological Dampers, Earthquake Engineering and Structural Dynamics 29: 557-575.

doi:10.1002/(SICI)1096-9845(200005)29:5<557::AIDEQE922>3.0.CO;2-X

\section{HIDRAULINIO İ GREITĮ IR POSLINKĮ REAGUOJANČIO SLOPINTUVO (HGPS) ELGSENA, SKLEIDŽIANT ENERGIJĄ IR GERINANT SEISMINES KONSTRUKCIJOS CHARAKTERISTIKAS}

\section{Wen-Pei Sung, Ming-Hsiang Shih, Yu-Kuang Zhao}

\section{Santrauka}

Siūlomas naujas hidraulinis ị greitị ir poslinkị reaguojantis slopintuvas (HGPS), sukurtas prie droselinio vožtuvo su kintama apertūra pridejjus atbulini vožtuvą. Buvo siekiama užtikrinti geresnę adaptyvią konstrukcijos judèjimo žemès drebèjimo metu kontrolę keičiant HGPS slopinimo koeficientą. Norint modeliuoti tikraji energijos pašalinimą, buvo sukurtas matematinis modelis, pagrisstas Maksvelo modeliu. Šis modelis buvo pakeistas prie trinties modelio pridejus nuoseklujji trinties modelị ir nedideli slopintuvą. Matematinio modeliavimo rezultatai lyginami su tikraja siūlomo gesintuvo energijos sklaida. Palyginimas rodo, kad matematinio modeliavimo rezultatai atitinka tikrają siūlomo gesintuvo elgseną. Lyginant skaičiavimo rezultatus su eksperimentiniais matyti, kad siūlomas matematinis modeliavimas leidžia tiksliai išreikšti jẻgos ir poslinkio bei jègos ir greičio ryšius, susidarančius energijos sklaidos metu. Laboratoriniai rezultatai, gauti naudojant vibracinị stala, ir modeliavimo rezultatai taikomi tirti bei tikrinti siūlomo gesintuvo įtaką mažinant seismines konstrukcijos charakteristikas. Eksperimentiniai ir modeliavimo rezultatai rodo, kad nepaisant žemès drebejjimo laipsnio, siūlomas gesintuvas labai pagerina konstrukcijos poslinkių kontrolę efektyviai mažindamas judèjimo pagreiti.

Reikšminiai žodžiai: HGPS, Maksvelo modelis, diskretusis sprendinys, pasyvusis energijos skaidos prietaisas, vibracinio stalo bandymas, modeliuojamas konstrukcijos reakcijos mažinimas. 
Wen-Pei SUNG is a Professor at the Department of Landscape Architecture and Dean, Integrated research center for green living technologies, National Chin-Yi University of Technology, Taiwan. He is also a Member of Committee, Public Construction Commission, Executive Yuan, Taiwan and a certified Professional Engineer of Structural Engineering. His research interests are in Techniques of Structural Control, Numerical Analysis, integrated Research for Green Living Techniques, Construction Management.

Ming-Hsiang SHIH is a Professor at the Department of Civil Engineering, National Chi-Nan University, Taiwan. His research interests are in the Earthquake Engineering: Structural Control, Semi-Active Damper and Isolation; Experimental Technique: Dynamic Testing, Application of Digital Image to Measurement, On-Line Monitoring, Experimental Biomechanics; Computers and Programming: Numerical Methods, Finite Element Method, Nonlinear Model, Computer aided Monitoring and Control and Green Engineering: Combination of Solar and Geothermal Energy. He has already developed many passive, semi-active hydraulic dampers and also published many research papers about these devices. Recently, he is developing Digital Imagine Correlation Method, DIC, applied in structural health monitoring for bridge and building structure.

Yu-Kuang ZHAO is an Associate Professor at Institute of Refrigeration, Air Conditioning and Energy Technology and Deputy Dean Integrated research center for green living technologies, National Chin-Yi University of Technology, Taiwan. His research interests are in Vibration Control, Difference Function, Integrated Research for Green Living Techniques. 